Original Article

\title{
COMPARATIVE STUDY OF ANTIDEPRESSANT-LIKE EFFECT OF THE LEAVES OF SAPINDUS EMARGINATUS AND ACORUS CALAMUS IN EXPERIMENTAL ANIMAL MODELS
}

\author{
PRIYADARSHINI SHOUGRAKPAM, ABHISHEK BHATTACHARJEE, MAYANGLAMBAM MEDHABATI, NGANGOM \\ GUNINDRO
}

Department of Pharmacology, Regional Institute of Medical Sciences, Imphal, India

Email: drmedhabati@gmail.com

Received: 14 Sep 2020, Revised and Accepted: 17 Nov 2020

\section{ABSTRACT}

Objective: Depression is an affective disorder characterized by a change in mood, lack of confidence, lack of interest in surroundings and many natural products that have been tried to treat the disease. The study was aimed to evaluate and compare the antidepressant activity of methanol leave extract of SapindusemarginatusVahl. (MESE) and Acoruscalamus Linn. (MEAC) in experimental models in albino mice.

Methods: Methanol Extracts of the plants were prepared by soxhlet extraction method. Forced swimming test (FST) and Tail suspension test (TST) models were chosen to evaluate antidepressant activity.Albino mice were selected and divided into six groups of six animals for each experimental model. Group I received 1\% gum acacia in distilled water (DW) at a dose of $1 \mathrm{ml} / 100 \mathrm{~g}$ orally. Group II received sertraline-10 mg/kg orally. Group III and IV were administered 200 and $400 \mathrm{mg} / \mathrm{kg}$ of MESE respectively. Group V and VI were treated with 200 and $400 \mathrm{mg} / \mathrm{kg}$ of MEAC, respectively.

Results: Methanol extracts of Sapindusemarginatus and Acoruscalamus at the two different doses of 200 and $400 \mathrm{mg} / \mathrm{kg}$ demonstrated a significant decrease in immobility time when compared with the control in both animal models. The extracts at the higher dose of $400 \mathrm{mg} / \mathrm{kg}$ revealed a significant reduction in immobility time compared to $200 \mathrm{mg} / \mathrm{kg}$ of the same extract.

Conclusion: The results suggest that the methanol extracts of SapindusemarginatusVahl. andAcoruscalamus Linn. possessthe anticonvulsant activityand justify their use in folk medicine.

Keywords: Sapindusemarginatus, Acoruscalamus, FST, TST, Antidepressant

(C) 2021 The Authors. Published by Innovare Academic Sciences Pvt Ltd. This is an open access article under the CC BY license (https://creativecommons.org/licenses/by/4.0/) DOI: https://dx.doi.org/10.22159/ijcpr.2021v13i1.40800. Journal homepage: https://innovareacademics.in/journals/index.php/ijcpr

\section{INTRODUCTION}

Depression is an affective disorder characterized by a change in the mood, lack of confidence, lack of interest in surroundings and the severity may range from mild to severe [1]. About 450 million people suffer from mental or behavioral disorders. Depression will become the second leading cause of premature death or disability worldwide by the year 2020.A large percentage of patients suffering from depression respond to the currently available antidepressants, but the extent of improvement is still disappointing because of various side effects and drug tolerance [2].Till today, there are many unmet clinical needs with respect to the efficacy and adverse effects of the variousantidepressants. To address these needs, antidepressants with novel mechanisms and fewer side effects are in great demand [3].

It is a fact that many natural products and synthetically modified natural product derivatives have been successfully developed for clinical use to treat human diseases in almost all therapeutic domains [4].The treatment and control of diseases by using locally available medicinal plants will continue to play significant roles in medical health care implementation in developing countries [5].

Globally herbal medicines are extensively used due to their therapeutic efficiency and minimum side effects in neurological disorders; therefore, investigations for the search of novel and better-tolerated molecules from plant sources have progressed in recent years demonstrating the pharmacological effectiveness of different plant species in a variety of animal models [6]. However, to the best of our knowledge, there is no single scientific report demonstrating the anti-depressant activity of Sapindusemarginatusand Acoruscalamus. Current investigation aimed at evaluating the antidepressant potential ofSapindusemarginatusand Acoruscalamus.Depressionrepresents one of the major health problems among other mood disorders worldwide. Theuse of suitable animal models is essential for understanding of the neurobiological basis of mood disorders and is facilitating the approaches for thediscovery of novel therapeutic targets. Forced Swim Test (FST) and Tail Suspension Test (TST) are employed as exemplary systems to probe depressing condition in rodents [7].

Immobility or despair behaviour produced in both FST and TST were hypothesized to display animal's hopelessness and low mood (behavioural despair), and are taken as paradigm of depression. This simple behavioural procedure is a widely used test for screening novel antidepressants [7].

There are number of pharmacological studies on Sapindusemarginatusand Acoruscalamus in the literature. Some studies reported the potentials of the two plants as anticonvulsants. Depression is a mood disorder often accompanied with convulsive disorders in humans. Therefore, we also focused on the evaluation and comparison of the effects of the two plants on depression models.

\section{MATERIALS AND METHODS}

Approval of institutional animal ethics committee (IAEC)

The study was conducted in the Department of Pharmacology, Regional Institute of Medical Sciences, Imphal, after getting approval of the Institutional Animal Ethics committee, RIMS, Imphal (No.1596/GO/a/12/CPCSEA).

\section{Requirements}

Albino mice, polypropylene cages, feeding tubes, Plexiglas cylinder (height-20 cm, diameter $-15 \mathrm{~cm}$ ), distilled Water, towels, warming lamp, horizontal ring-stand bar, adhesive tape, stopwatch, marker, measuring tape, petroleum ether, methanol, soxhlet apparatus,plant extracts, mixer grinder, evaporating dish, gum 
acacia and sertraline tablet (Intas Pharmaceutical, Selaqui, Dehradun, B. No DT2703).

\section{Preparation of plant extract}

SapindusemarginatusVahl. andAcoruscalamusLinn. were collected fromImphal valley in the month of August-September 2016. The plants were identified and authenticated by Prof. PK Singh, Department of Life Sciences, Manipur University (Acc. no. MUMP0197 and MUMP-1423).

The methanol extract of Sapindusemarginatus (MESE) and Acoruscalamus (MEAC) were prepared by the method described by Lin J et al.[8]The leaves were cleaned, air-dried under the shade and powdered by a mixture grinder.The powdered materials of the two plants were extracted separately with methanol after defatting with petroleum ether using soxhlet apparatus. The extracts obtained were evaporated, scraped out and stored in an airtight container. The yield obtained was $10 \%$ and $6 \%$ for Sapindusemarginatus and Acoruscalamus, respectively [8].

\section{Phytochemical screening}

The preliminary phytochemical tests of the plant extracts were carried out using standard procedures $[9,10]$.

\section{Experimental animals}

Healthy albino mice of either sex weighing approximately 25-30 g were obtained from the Animal House, RIMS, Imphal. These animals were acclimatized to the laboratory conditions for $7 \mathrm{~d}$ before the experiment. The animals were housed in the departmental animal room in groups in polypropylene cages at room temperature with natural light and dark cycle. They were housed in groups of 6 animals per cage and maintained on a standard animal diet with water adlibitum.

\section{Acute toxicity testing}

The acute toxicity testing was carried out as per OECD guidelines 423[11] in albino mice. Three animals were used for each step. The plant extracts i.e. MESE (methanol extract of Sapindusemarginatus) and MEAC (methanol extract of Acoruscalamus) were administered to the fasted mice at a dose of $300 \mathrm{mg} / \mathrm{kg} \mathrm{p}$. o. and observed once in every 30 min during the first $24 \mathrm{~h}$ and thereafter, daily for $14 \mathrm{~d}$. As there was no mortality, the procedure was repeated with a higher dose of $2000 \mathrm{mg} / \mathrm{kg}$, and the animals were observed for mortality and toxic symptoms. It was observed that the dose of $2000 \mathrm{mg} / \mathrm{kg} \mathrm{p}$. o. of the plant extracts caused no mortality or toxic symptoms in the tested animals and the dose was considered safe. Two doses of 200 $\mathrm{mg} / \mathrm{kg}\left(1 / 10^{\text {th }}\right.$ of the maximum test dose $)$ and $400 \mathrm{mg} / \mathrm{kg}\left(1 / 5^{\text {th }}\right.$ of the maximum test dose) of the plant extracts were selected as working doses for the experiment.

\section{Selection of animals}

Animals were subjected to a pre-test assessment.For the Forced swim test (FST), mice were placed gently and slowly by holding its tail in the water inside a vertical Plexiglas cylinder containing fresh water $\left(25^{\circ} \pm 1^{\circ} \mathrm{C}\right)$ upto a height of $12 \mathrm{~cm}$ for $2 \mathrm{~min}$. Thirty-six mice showing vigorous movement to escape from the water during the session were selected.

For Tail suspension test (TST), the animals were suspended from a horizontal bar $30 \mathrm{~cm}$ above the surface with an adhesive tape placed $2 \mathrm{~cm}$ away from the tip of the tail for 2 min. Thirty-six mice showing alternating agitation and immobility during the session were selected.

\section{Experimental design}

For both the FST and TST, selected mice were divided into six groups (I, II, III, IV, V and VI) of 6 animals each.The mice in group I (Control) were given $1 \%$ gum acacia in distilled water (DW) at the dose of 1 $\mathrm{ml} / 100 \mathrm{~g}$ orally. The group II (Standard) animals were treated with sertraline $-10 \mathrm{mg} / \mathrm{kg}$. The mice in group III and IV were made to receive 200 and $400 \mathrm{mg} / \mathrm{kg}$ of MESE, respectively. The group $\mathrm{V}$ and VI mice were treated with 200 and $400 \mathrm{mg} / \mathrm{kg}$ of MEAC, respectively. Sertraline and the test drugs i.e. MESE and MEAC were suspended in $1 \%$ gum acacia in $\mathrm{D} / \mathrm{W}$ in such a way that $1 \mathrm{ml}$ of the suspension contained the calculated doses of the drugs and given orally (p. o.) once daily using feeding tubes for 7 consecutive days.After overnight fasting on the next day, mice in each group were evaluated after $1 \mathrm{~h}$ of drug administration. The experiments were carried out in a quiet room under controlled light conditions between 11:00 a. m. and 3:00 p. m.

\section{Procedure}

\section{Forced swim test (FST)}

The principle adopted by Porsoltet al.[12] was followed. The animals were forced to swim for a period of $6 \mathrm{~min}$ inside a vertical plexiglas cylinder containing freshwater $\left(25^{\circ} \pm 1^{\circ} \mathrm{C}\right)$ upto a height of $12 \mathrm{~cm}$. The duration of immobility that alternates with phase of enhanced motor activity was recorded during the last $4 \mathrm{~min}$ of the total testing period.During initial $2 \mathrm{~min}$ of the test, there were vigorous swimming activities and attempts of trying to escape by diving or climbing the walls of the cylinder.Duration of immobility in the control and various treatment groups were compared. Decrease in the duration of immobility was considered as an index of antidepressant activity. The animal wasjudged to be immobile whenever it remains floating passively in the water in a slight hunched but upright position with its nose just above the surface. Following the swimming session, the mice were taken out of water, mopped with towels and kept warmed using lamps to prevent hypothermia before being returned to the cages. Water in the cylinder was changed after each swimming session.

\section{Tail suspension test}

The test was performed according to the method described byDuszczyk M et al.[13]The animals were hung by the tail from a horizontal ring-stand bar $30 \mathrm{~cm}$ above the surface with an adhesive tape placed $2 \mathrm{~cm}$ away from the tip of the tail. The duration of immobility was observed for a period of $6 \mathrm{~min}$. Mice were considered immobile only when they hung passively and completely motionless. The period of immobility in the control and various treated groups were compared. The decrease in the immobility period was considered as an index of antidepressant activity.

\section{Analysis of results}

The results were expressed as mean \pm standard deviation (SD) and analyzed by One-way analysis of variance (ANOVA) followed by Bonferroni test. P-value less than 0.05 was considered significant. IBM SPSS statistics version 21 was used for the analysis.

\section{RESULTS}

\section{Phytochemical screening}

The preliminary qualitative phytochemical analysis of methanol extract of Sapindusemarginatusrevealed the presence of alkaloids, carbohydrates, flavonoids, saponins, tannins, gums and proteins, while the extract of Acoruscalamus revealed the presence of flavonoids, saponins, tannins, alkaloids and starch.

\section{Forced swim test}

The mean duration of immobility (sec) in various groups treated with control, Sertraline- $10 \mathrm{mg} / \mathrm{kg}$, MESE- $200 \mathrm{mg} / \mathrm{kg}$, MESE-400 $\mathrm{mg} / \mathrm{kg}, \mathrm{MEAC}-200 \mathrm{mg} / \mathrm{kg}$ and MEAC- $400 \mathrm{mg} / \mathrm{kg}$ were $177.67 \pm 15.83$, $56.83 \pm 4.75,93.67 \pm 13.11,54.33 \pm 17.61,110 \pm 6.38$ and $63 \pm 13.08$ respectively. In the groups treated with Sertraline- $10 \mathrm{mg} / \mathrm{kg}, 200$ and $400 \mathrm{mg} / \mathrm{kg}$ of MESE and MEAC, the duration of the immobility decreased significantly $(\mathrm{P}<0.001)$ when compared with the control. The period of immobility in the groups treated with $400 \mathrm{mg} / \mathrm{kg}$ of MESE and MEAC and Sertraline-10 mg/kg were comparable. However, the Sertraline treated group demonstrated significantly shorten $(\mathrm{P}<0.001)$ period of immobility when compared with the groups treated with $200 \mathrm{mg} / \mathrm{kg}$ of MESE and MEAC. The extracts at the dose of $400 \mathrm{mg} / \mathrm{kg}$ demonstrated significantly $(\mathrm{P}<0.001)$ shorter duration of immobility when compared with their lower doses i.e. $200 \mathrm{mg} / \mathrm{kg}$. In the MESE- $400 \mathrm{mg} / \mathrm{kg}$ treated group, the immobility period was significantly $(\mathrm{P}<0.001)$ less when compared with the groups treated with MEAC- $200 \mathrm{mg} / \mathrm{kg}$, and the so also duration of immobility was shorten significantly $<(\mathrm{P} .01)$ in the MEAC -400 
$\mathrm{mg} / \mathrm{kg}$ treated group when compared with MESE-200 mg/kg treated group.However, the immobility periods in the group treated with

Table 1: Effect on the duration of immobility in forced swim test (FST)

\begin{tabular}{|c|c|c|}
\hline Treatment group & Duration of immobility(second) & \\
\hline I. Control-1\%gum acacia susp. & $177.67 \pm 15.83$ & \\
\hline II. Sertraline- $10 \mathrm{mg} / \mathrm{kg}$ & $56.83 \pm 4.75^{*}+$ & \\
\hline MESE- $200 \mathrm{mg} / \mathrm{kg}$ & $93.67 \pm 13.11^{*}$ & \\
\hline V. MESE-400 mg/kg & $54.33 \pm 17.61^{* \ddagger \#}$ & \\
\hline V. MEAC- $200 \mathrm{mg} / \mathrm{kg}$ & $110.00 \pm 6.38^{*}$ & \\
\hline 'I. $\quad \mathrm{MEAC}-400 \mathrm{mg} / \mathrm{kg}$ & $63.00 \pm 13.08^{*} \neq \S$ & \\
\hline One way ANOVA & F83.1 & $\mathrm{P}<0.001$ \\
\hline
\end{tabular}

Values are mean $\pm \mathrm{SD}, \mathrm{n}=6 ;{ }^{*} \mathrm{P}<0.001$ when compared with control, ${ }^{\mathrm{P}}<0.001$ when compared with $\mathrm{MESE}-200 \mathrm{mg} / \mathrm{kg}$ and $\mathrm{MEAC}-200 \mathrm{mg} / \mathrm{kg},{ }^{\ddagger} \mathrm{P}<0.001$ when compared with $200 \mathrm{mg} / \mathrm{kg}$ of same extract, ${ }^{\mathrm{P}}<0.001$ when compared with MEAC-200 mg/kg, §P<0.01 when compared with MESE-200 $\mathrm{mg} / \mathrm{kg}$.(One way ANOVA followed by Bonferroni test).

\section{Tail suspension test}

The mean duration of immobility (sec) in various groups treated with control, Sertraline- $10 \mathrm{mg} / \mathrm{kg}$, MESE- $200 \mathrm{mg} / \mathrm{kg}$, MESE-400 $\mathrm{mg} / \mathrm{kg}$, MEAC-200 $\mathrm{mg} / \mathrm{kg}$ and MEAC-400 $\mathrm{mg} / \mathrm{kg}$ were $166.33 \pm 4.50,57.83 \pm 5.60,144.83 \pm 8.28,106.67 \pm 7.50,153.50 \pm 8.46$ and $114 \pm 4.94$ respectively. The durations of immobility were significantly reduced in the Sertraline, MESE and MEAC treated groups when compared with the control group. The Sertraline treated group shortens the period of immobility significantly $(\mathrm{P}<0.001)$ when compared with the groups treated with 200 and
$400 \mathrm{mg} / \mathrm{kg}$ of the two extracts. The group receiving $400 \mathrm{mg} / \mathrm{kg}$ of the extracts demonstrated a significantly shorter $(\mathrm{P}<0.001)$ duration of immobility when compared with their lower doses i.e. $200 \mathrm{mg} / \mathrm{kg}$. In the MESE-400 mg/kg treated group, the immobility period was significantly $(\mathrm{P}<0.001)$ decreased when compared with the group treated with MEAC- $200 \mathrm{mg} / \mathrm{kg}$. Significantly shorten $(\mathrm{P}<0.01)$ immobility time was also observed in MEAC $-400 \mathrm{mg} / \mathrm{kg}$ treated group when compared with the MESE-200 mg/kg treated group. The immobility periods in the group treated with equal doses of the extracts were comparable.

Table 2: Effect on duration of immobility in tail suspension test

\begin{tabular}{|c|c|c|}
\hline Treatment group(p. o.) & Duration of immobility(second) & \\
\hline I. Control-1\%gum acacia susp. & $166.33 \pm 4.50$ & \\
\hline II. Sertraline $-10 \mathrm{mg} / \mathrm{kg}$ & $57.83 \pm 5.60 * \dagger$ & \\
\hline [I. MESE-200 mg/kg & $144.83 \pm 8.28^{*}$ & \\
\hline V. MESE-400 mg/kg & $106.67 \pm 7.50^{*} \neq \#$ & \\
\hline V. $\quad$ MEAC-200 mg/kg & $153.50 \pm 8.46^{* *}$ & \\
\hline 'I. MEAC-400 mg/kg & $114 \pm 4.94^{*} \ddagger \S$ & \\
\hline One way ANOVA & F208.2 & $\mathrm{P}<0.001$ \\
\hline
\end{tabular}

Values are mean $\pm \mathrm{SD}, \mathrm{n}=6,{ }^{*} \mathrm{P}<0.001,{ }^{* *} \mathrm{P}<0.05$ when compared with control, ${ }^{\dagger} \mathrm{P}<0.001$ when compared with MESE and MEAC treated groups, ${ }^{\ddagger} \mathrm{P}<0.001$ when compared with $200 \mathrm{mg} / \mathrm{kg}$ of the same extracts, ${ }^{\mathrm{P}}<0.001$ when compared with MEAC-200 mg/kg, ${ }^{\S} \mathrm{P}<0.01 \mathrm{when}$ compared with MESE-200 $\mathrm{mg} / \mathrm{kg}$. (One way ANOVA followed by Bonferroni test).

\section{DISCUSSION}

Mice are commonly used rodents which are small, easily housed and maintained. Interestingly, the genetic, biological and behavioural characteristics of the rodents closely resemble to those of humans. Various human disorders, including behavioural disorders and seizures are studied in suitable mice models [13].

The Forced swim test (FST) and Tail suspension test (TST) are widely accepted behavioural models for the assessment of antidepressant activity. It is well known that many antidepressant drugs are able to reduce immobility time in rodents in the above models [14]. The forced swimming induced state of immobility in animals is claimed to represent a condition similar to human depression [15]. However, TST is considered to have greater pharmacological sensitivity than FST for antidepressants acting through selective inhibition of serotonin reuptake[16]. Both the methanol extracts of Sapindusemarginatus and Acoruscalamus at the two different doses of 200 and $400 \mathrm{mg} / \mathrm{kg}$ demonstrated decreased immobility time when compared with the control in both animal models and this observationis strongly suggestive of theirantidepressant property. The extracts at the higher dose of 400 $\mathrm{mg} / \mathrm{kg}$ is more effective than the $200 \mathrm{mg} / \mathrm{kg}$ dose. However, the antidepressant activity was not significantly different between similar doses of the plant extracts.

The biochemical basis of depression suggests that the disorder is linked with functional deficiency of the brain monoaminergic transmitters like norepinephrine (NE), 5-HT (serotonin) and/or dopamine (DA)[17]. Practically all antidepressants affect monoaminergic transmission in the brain in one way or the other and a large number of antidepressants with effects on reuptake/metabolism of biogenic amines, and on pre/postjunctionalaminergic/cholinergic receptors have also been known.The standard drug, sertraline is a popular antidepressant that blocks the reuptake of serotonin into the neurons resulting to increased serotonin availability at its receptors in the CNS[18].

The qualitative analysis of methanol extract of Sapindusemarginatus and Acoruscalamus revealed the presence of phytochemicals such as alkaloids, flavonoids, saponins, tannins and carbohydrates. The flavonoids such as hesperidin, naringenin, quercetin, and astilbin are reported to display antidepressant-like activity in animal experimental models [19]. Many flavonoids are inhibitors of MAO-A and-B [20].

Therefore, it may be assumed that the presence of the flavonoids in the two plant extracts might have contributed to the antidepressant activity.

\section{CONCLUSION}

The findings of our study reveal that the methanol extracts of Sapindusemarginatus and Acoruscalamus leaves possess antidepressant activity. Further studies with isolated biologically active principles of the plants in different models of depression will be more meaningful and interesting.

\section{ACKNOWLEDGEMENT}


The authors respectfully acknowledge the contribution of Dr. PK Singh, Professor, Department of Life Sciences, Manipur University in the authentication of the study plants.

\section{AUTHORS CONTRIBUTIONS}

All the authors have contributed equally.

\section{FUNDING}

Nil

\section{CONFLICTS OF INTERESTS}

Declared none

\section{REFERENCES}

1. Singh JN, Kumar S, Rana AC. Antidepressant activity of methanolic extract of FoeniculumVulgare (Fennel) fruits in experimental animal models. J Appl Pharm Sci 2013;3:65-70.

2. Onasanwo SA, Chatterjee M, Palit G. Antidepressant and anxiolytic potentials of dichloromethane fraction from Hedrantherabarteri. Afr J Biomed Res 2010;13:76-81.

3. Yu L, Jiang X, Liao M, Ma R, Yu T. Antidepressant-like effect of tetramethylpyrazine in mice and rats.Neurosci Med 2011;2:142-8.

4. Newman DJ, Cragg GM. Natural products as sources of new drugs over the last 25 y. J Nat Prod 2007;70:461-77.

5. Coolborn AF, Bolatito B. Antibacterial and phytochemical evaluation of three medicinal plants. J Nat Prod 2010;3:27-34.

6. Zhang ZJ. Therapeutic effects of herbal extracts and constituents in animal models of psychiatric disorders. Life Sci 2004;75:1659-99.

7. Alamgeer MNHM, Mushtaq MN, Bashir S, Ghumman SA, Akram $\mathrm{M}$, Khan HU,et al. Evaluation of some central nervous system (CNS) activities of aqueous methanolic extract of Paspalidiumflavidumlinn. J Med Plant Res 2012;6:3222-7.

8. Lin J, Opoku AR, Keller MG, Hutchings AD, Terblanche SE, Jager AK,et al. Preliminary screening of some traditional zulu medicinal plants for anti-inflammatory and anti-microbial activities. J Ethnopharmacol 1999;68:267-74.
9. Kokate CK, Purohit AP, Gokhale SB.Pharmacognosy. $45^{\text {th }}$ ed. Pune: NiraliPrakashan; 2009.

10. Shah B, Seth AK. Textbook of pharmacognosy and

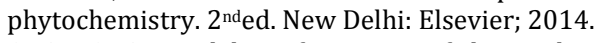

11. OECD. OECD guidelines for testing of chemicals 423:Acute oral toxicity-acute toxic class method. Paris; 2001. Available from: https://ntp.niehs.nih.gov/iccvam/suppdocs/feddocs/oecd/oec d_gl423.pdf. [Last accessed on 14 Sep 2018]

12. Porsolt R, Bertin A, Jalfre M. Behavioural despair in mice: a primary screening test for antidepressants. Arch IntPharmacodynTher 1977;229:327-36.

13. Melina R. Why do medical researchers use mice? 2010 Available from: https://www.livescience.com/32860-why-domedical-researchers-used-mice.html.[Last accessed on 12 Sep 2018]

14. DuszczykM, Gamdzyk M, Ziembowicz A, Boguszewski PM, Łazarewicz JW, Salińska E. Antidepressant-like and anxiolyticlike effects of mild hypobaric hypoxia in mice: possible involvement of neuropeptide Y. ActaNeurobiolExp(Wars) 2015;75:364-71.

15. CE Renard, E Dailly, DJ David, M Hascoet, M Bourin. Monoamine metabolism changes following the mouse forced swimming test but not the tail suspension test. FundamClinPharmacol 2003;17:449-55.

16. Cryan JF, Mombereau C, Vassout A. The tail suspension test as a model for assessing antidepressant activity: a review of pharmacological and genetic studies in mice. NeurosciBiobehav Rev 2005;29:571-625.

17. Bondy B. Pathophysiology of depression and mechanisms of treatment. Dialogues ClinNeurosci 2002;4:7-20.

18. Tripathi KD. Essentials of medical pharmacology. $8^{\text {th }} \mathrm{ed}$. New Delhi, Jaypee Brothers Medical Publishers; 2019.

19. Hritcu L, Ionita R,Postu PA, Gupta GK, Turkez H, Lima TC,et al. Antidepressant flavonoids and their relationship with oxidative stress.Oxid Med Cell Longev2017;1-18. Available from: https://www.hindawi.com/journals/omcl/2017/5762172/cit ations/.[Last accessed 10Sep 2018]

20. Jager AK, Saaby L. Flavonoids and the CNS. Molecules 2011;16:1471-85. 